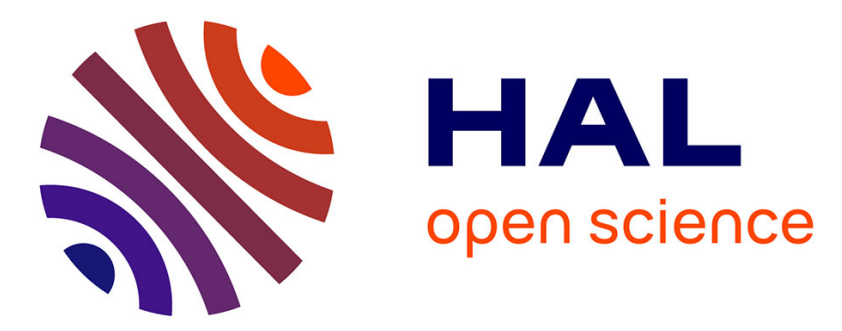

\title{
Benthic Dinoflagellate Integrator (BEDI): A new method for the quantification of Benthic Harmful Algal Blooms
}

Luisa Mangialajo, Anna Fricke, Gala Perez-Gutierrez, Daniela Catania, Cécile Jauzein, Rodolphe Lemee

\section{To cite this version:}

Luisa Mangialajo, Anna Fricke, Gala Perez-Gutierrez, Daniela Catania, Cécile Jauzein, et al.. Benthic Dinoflagellate Integrator (BEDI): A new method for the quantification of Benthic Harmful Algal Blooms. Harmful Algae, 2017, 64, pp.1 - 10. 10.1016/j.hal.2017.03.002 . hal-01501468

\section{HAL Id: hal-01501468 https://hal.sorbonne-universite.fr/hal-01501468}

Submitted on 4 Apr 2017

HAL is a multi-disciplinary open access archive for the deposit and dissemination of scientific research documents, whether they are published or not. The documents may come from teaching and research institutions in France or abroad, or from public or private research centers.
L'archive ouverte pluridisciplinaire HAL, est destinée au dépôt et à la diffusion de documents scientifiques de niveau recherche, publiés ou non, émanant des établissements d'enseignement et de recherche français ou étrangers, des laboratoires publics ou privés. 
Benthic Dinoflagellate Integrator (BEDI): a new method for the quantification of Benthic Harmful Algal Blooms

MANGIALAJO Luisa ${ }^{\mathrm{a}, \mathrm{b}}$, FRICKE Anna ${ }^{\mathrm{a}, \mathrm{b}}$, PEREZ-GUTIERREZ Gala ${ }^{\mathrm{a}}$, CATANIA Daniela $^{\mathrm{a}, \mathrm{b}}$, JAUZEIN Cécile ${ }^{\mathrm{a}}$, LEMEE Rodolphe ${ }^{\mathrm{a}}$

a Sorbonne Universités, UPMC Univ Paris 06, INSU-CNRS, Laboratoire d'Océanographie de Villefranche (LOV), Villefranche sur mer, France

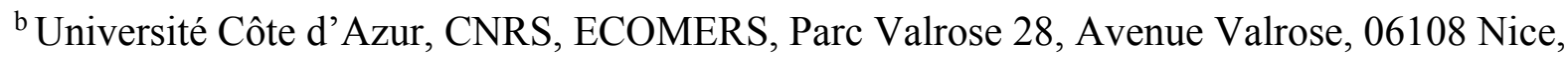
France

Corresponding author: Luisa Mangialajo, luisa.mangialajo@unice.fr 


\begin{abstract}
Despite the potential negative human health, ecological and economic impact, the ecology of harmful benthic dinoflagellate blooms remains largely unknown. This is probably due to the complex interactions among biotic and abiotic drivers that influence blooms, but also to the difficulty in quantifying cell abundance in a comparable way over large spatial and temporal scales. One of the recognized priorities for bHABs (benthic Harmful Algal Blooms) assessment is developing and standardizing methods that can provide comparable data. In this context, the Benthic Dinoflagellates Integrator (BEDI), a new non-destructive quantification method for benthic dinoflagellate abundances, has been developed and tested within the present study. The rationale behind the BEDI standard assessment method is that mechanical resuspension of cells enables the quantification of abundances as cells per unit of seabed surface area (i.e. cells $\mathrm{mm}^{-}$ ${ }^{2}$ ) or as Potentially Resuspended cells per unit of volume (PRcells $\mathrm{ml}^{-1}$ ), by integrating both cells in the biofilm and those in the surrounding water. Estimations of Ostreopsis performed with BEDI method are independent of the substratum (i.e. macroalgal species) or the dominant ecosystem (i.e. algal forests or turfs, seagrass beds, coral reefs) and potentially allow the comparison of benthic dinoflagellate blooms over broad temporal and spatial scales. The first application of the BEDI method, presented in this study, gave encouraging results: the characterization of blooms of Ostreopsis cf. ovata at three sites in the NW Mediterranean Sea is consistent with results derived from the other commonly applied methods. Quantification of the ratio between abundances of cells in the biofilm and in the surrounding water was calculated for the first time per unit of seabed surface area, demonstrating that the highest abundances of cells (the stock), and therefore the associated risk for human health, are in the biofilm. For risk assessment purposes, conversion values for commonly used monitoring alert thresholds of Mediterranean Ostreopsis blooms are provided.
\end{abstract}


Keywords: HABs; Benthic dinoflagellates; Ostreopsis; Sampling; Monitoring; Risk assessment

Highlights

- The BEDI (Benthic Dinoflagellate Integrator) is a new method for the quantification of benthic dinoflagellates

- It estimates cell abundances per surface area of seabed (cells $\mathrm{mm}^{-2}$ ), independently of the substratum

- It can provide quantitative data comparable over large temporal and spatial scales

- It estimates the Potentially Resuspended Cells per unit of volume (PRCells ml ${ }^{-1}$ ), a direct measure of health risk associated with Ostreopsis blooms

- Estimations of Ostreopsis performed with BEDI are consistent with the currently used methods of benthic bloom quantification 
Introduction

Potentially harmful benthic dinoflagellate blooms, well known in tropical latitudes, are increasing in distribution and frequency in temperate areas (Shears and Ross 2009; Litaker et al., 2010; Parsons et al., 2011; Rhodes, 2011). In the tropics, the genus Gambierdiscus is responsible for the ciguatera fish poisoning, but other benthic dinoflagellates, such as Ostreopsis and Prorocentrum, contain toxins and therefore have the potential to contribute to seafood poisoning (see overview in Nakajima et al., 1981; Yasumoto et al., 1987; Richlen \& Lobel, 2011). The true extent and potential impact of benthic dinoflagellate-based sea-foodborne illnesses on human communities remains under-studied (Skinner et al., 2011). In temperate areas, Gambierdiscus is generally absent or very localized (Parsons et al., 2012), while blooms of the genus Ostreopsis are considered as an emergent phenomenon. They are responsible for several sporadic human health issues, including skin irritations due to physical contact (Tubaro et al., 2011), as well as outbreaks of mass respiratory symptoms in beach-goers exposed to marine aerosols (Gallitelli et al., 2005; Durando et al., 2007; Barroso Garcia et al., 2008; Ciminiello et al. 2014; Vila et al., 2016). Sporadic shellfish contamination (Aligizaki et al., 2008, Brissard et al, 2014; Biré et al., 2013; 2015) and mass mortality of invertebrates (Granéli et al., 2002; Sansoni et al., 2003; Shears and Ross 2009; Totti et al., 2010) are also associated with Ostreopsis blooms in temperate latitudes, with potential cascade effects at the ecosystem level (Shears and Ross, 2010).

Despite the potential human health, ecological and economic impact, bHABs (benthic Harmful Algal Blooms) ecology is still poorly understood worldwide. Climate change (Shears and Ross, 2010; Granéli et al., 2011; Llewellyn, 2010;) and human impact (i.e. nutrient levels, Accoroni et al., 2015; Litaker et al., 2010; Parsons and Preskitt, 2007; Skinner et al., 2013) have been suggested as potential drivers of blooms, but remain poorly understood. This is probably due to the complex interactions among biotic and abiotic drivers that influence these blooms (Cohu et al., 2013; Accoroni et al., 2015; Accoroni and Totti, 2016), but also to the difficulty in quantifying cell abundance in a comparable way over broad spatial and temporal scales (Mangialajo et al., 2011; Berdalet et al., 2012; Zingone et al., 2012).

Benthic dinoflagellates thrive in shallow waters, growing mostly on macroalgae and hard substrates (e.g. rocks, corals, mollusc shells), where they can form a biofilm. They exhibit host preferences (see Parsons and Preskitt, 2007 and references therein) and can detach from the substrate and swim in the surrounding water (Rains and Parsons, 2015). As benthic dinoflagellates are loosely attached to the substrate, they can also be easily resuspended by 
mechanical action (e.g. waves, anchoring, trampling). They can therefore be found in large quantities in the surrounding water and can form mucilaginous aggregates floating at the surface (See Ostreopsis cf. ovata bloom dynamics in Fig. 1). Different techniques for quantifying cell abundance have been applied for research, monitoring and risk assessment purposes (Berdalet et al., 2012 and Tester et al., 2014 for reviews). The two most common assessment methods involve the quantification of cells in the biofilm, expressed as cells $\mathrm{g}^{-1}$ of collected macroalga or per surface area of different substrates (i.e. pebbles, corals, shells), and the quantification of cell concentrations in the surrounding water, usually expressed as cells $1^{-1}$. Alternative methods for quantifying benthic dinoflagellate cell abundances independently of their natural substrates have been tested, including the application of suction apparatus which gives representative abundances of the cells in the biofilm (Parsons et al., 2010; Abbate et al., 2012), or the deployment of artificial substrates which integrate over time the cells in the surrounding water (Tester et al., 2014; Jauzein et al., 2016). None of these promising methods have been applied to date over wide spatial and temporal scales with the aim of finding global common patterns for bHABs.

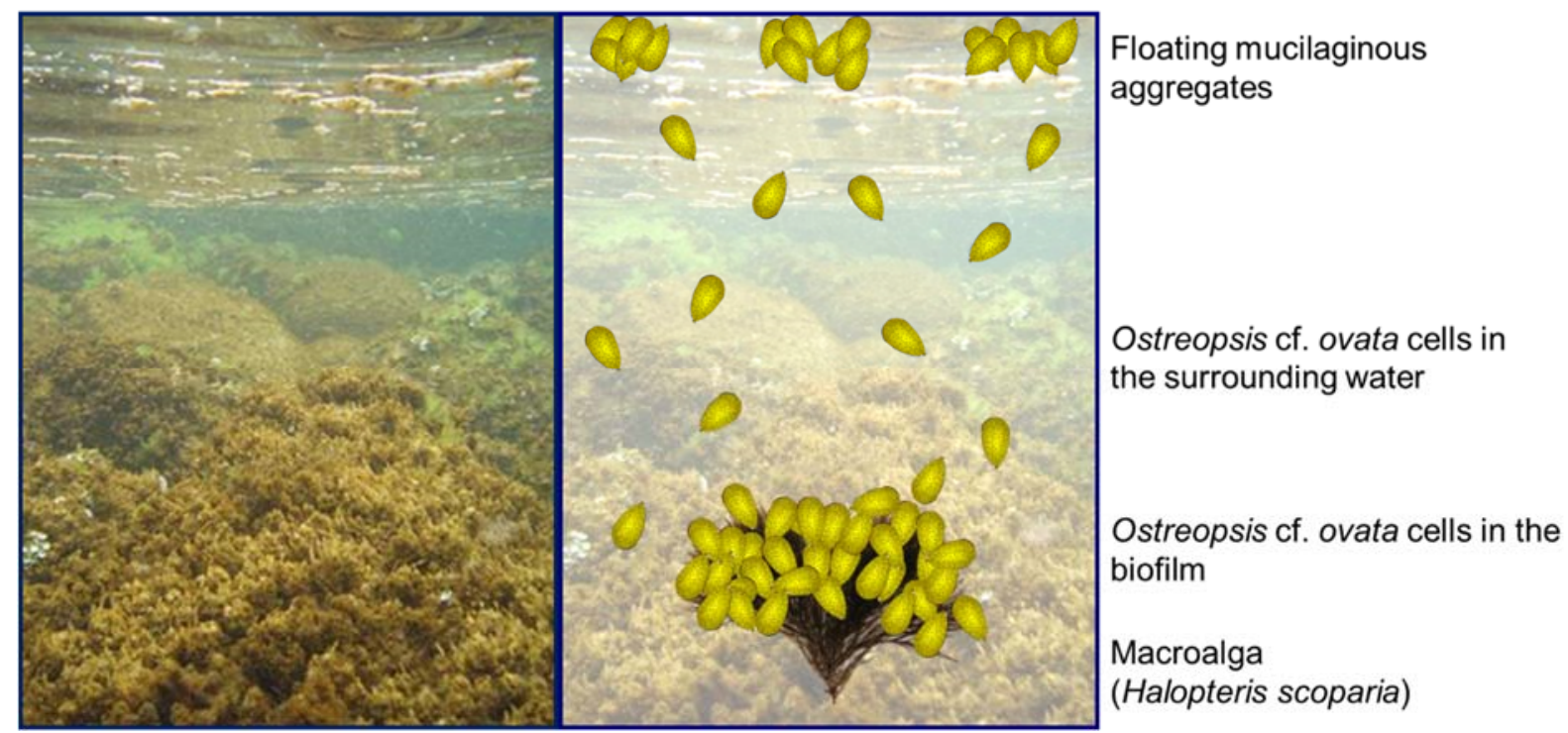

Fig. 1. Typical Ostreopsis cf. ovata bloom in the North Western Mediterranean Sea. Left: macroalgal communities covered by brownish Ostreopsis cf. ovata biofilm. Right: schematic representation of Ostreopsis cf. ovata bloom component: Ostreopsis cf. ovata cells in the brownish biofilm developing on macroalgal communities, Ostreopsis cf. ovata cells free swimming or resuspended in the surrounding water and mucilaginous aggregates floating at the surface. 
The quantification of benthic dinoflagellates in the biofilm (calculated as cells $\mathrm{g}^{-1}$ of macroalgae) is commonly used for bHABs in tropical areas (see Tester et al., 2014 and references therein). This measure plays a crucial role in terms of risk assessment of ciguatera poisoning, as cells adhering to the macrophytes can enter the food web via the grazing of herbivores. The measure of cells $\mathrm{g}^{-1}$ of macroalgae is therefore the most widespread method, but results are species-specific (dependent on the specific weight and morphology of the different macroalgal host species). The assessment of cells in the biofilm is also a widespread method for temperate bHABs, as demonstrated in a recent synthesis of results from different research teams in the Mediterranean Sea (Mangialajo et al., 2011). Due to the variety of macroalgal species collected as substrates at the investigated scale, this synthesis could not provide direct comparisons of bloom magnitudes. In order to describe general trends of bloom dynamics, the authors decided to focus their work on the relative maximum annual value, but this prevented them from finding general patterns in absolute magnitude of blooms (Mangialajo et al, 2011). In order to overcome the issue of substrate diversity, the idea of assessing the number of cells per surface unit area of the host macroalga (therefore independent of the weight) had been suggested in the past (Bomber et al., 1985; Lobel et al., 1988) and has been tested more recently (Totti et al., 2010). While this standardization is promising, the calculation of macroalgal surface areas (variable as a function of the precision used for the measurement) remains a major constraint.

In temperate areas, the risk of outbreaks of skin and ear, nose, throat irritation in addition to respiratory problems is mostly associated with the abundance of Ostreopsis spp. cells in the water, on the surface (the characteristic floating mucilaginous aggregates) and therefore in the aerosols. Quantification of cells is therefore often also performed on water samples taken a few dozen centimeters from the macroalgal assemblages (surrounding water) and bloom magnitude is expressed as cells $1^{-1}$ ). Since this is an easier sampling procedure both in the field and in the laboratory (no macroalgal separation and identification are needed), this measurement method is often preferred to the quantification of cells $\mathrm{g}^{-1}$ of macroalgae, especially in monitoring and in risk assessment studies (i.e. Funari et al., 2015). Nevertheless, the concentration of cells in the water can be highly variable during the day (Vila et al., 2001) and as a function of local hydrodynamic conditions (sea breezes, boat circulation, trampling by beachgoers) and the reliability of such measurements in the framework of risk assessment is still debated.

In conclusion, the two widespread 'biofilm' and 'surrounding water' assessment approaches present various advantages and disadvantages (Table 1). In general, scientists agree that the 
quantification of cells in the biofilm is more accurate than that of concentrations of cells in the surrounding water, which is dependent on local resuspension due to mechanical action and daily migration of cells. It is assumed to be more representative of the stock of cells (i.e. Mangialajo et al., 2011) and therefore of the potential risk due to cell resuspension. Unfortunately, to date it has not been possible to assess the relative abundance of cells in the biofilm and in the surrounding water at a given time, because of the lack of a sampling technique allowing a precise calculation of cell abundance in the biofilm over a given surface area of seabed. On the other hand, the quantification of cells in the biofilm requires the collection of macroalgae and is therefore an ecologically destructive method that should be avoided for large scale monitoring. Furthermore, it provides substrate-dependent measures, and does not allow the comparison of blooms over large spatial and temporal scales.

The purpose of the present study was therefore to develop and test a new non-destructive sampling method for quantifying benthic dinoflagellate blooms worldwide in a simple, reliable and comparable way that may be applied both for scientific research and for monitoring purposes, the Benthic Dinoflagellates Integrator (BEDI). The rationale behind the BEDI method is that mechanical resuspension of cells allows the quantification of abundances as cells per surface unit area of seabed (i.e. cells $\mathrm{mm}^{-2}$ ) by integrating both cells in the biofilm and in the surrounding water. These measures are independent of the substratum (i.e. macroalgal species) and can also be expressed as Potentially Resuspended cells per unit of volume (PRcells $\mathrm{ml}^{-1}$ ) that may be used, at least in the case of Ostreopsis cf. ovata blooms, as a direct measure of the risk associated with inhalation of aerosols.

The first application of the BEDI to an Ostreopsis cf. ovata bloom is presented in this study. The characterization of blooms at three sites in the Ligurian Sea has been performed with BEDI and classical estimations of biofilm (macroalgal sample) and surrounding water abundances, in order to compare the results and test its appropriateness for use for both research and monitoring purposes. The application of this new method allowed the first assessment of the relative abundances of Ostreopsis cf. ovata cells in the biofilm and in the surrounding water. Conversions to BEDI values of both monitoring and bloom definition thresholds are also provided. 
Table 1. Comparison of the different sampling methods applied (BEDI, biofilm, surrounding water estimations). Various advantages (in bold) and disadvantages corresponding to each method are given for the whole procedure, from field collection to the subsequent sample treatment and counting in the laboratory.

\begin{tabular}{|c|c|c|c|}
\hline & $\begin{array}{l}\text { SURROUNDING } \\
\text { WATER estimations } \\
\left(\text { cells } 1^{-1}\right)\end{array}$ & $\begin{array}{l}\text { BIOFILM } \\
\text { estimations } \\
\text { (cells g }{ }^{-1} \text { of macroalgae) }\end{array}$ & $\begin{array}{l}\text { BEDI } \\
\text { estimations } \\
\left.(\text { cells cm})^{-2}\right)\end{array}$ \\
\hline $\begin{array}{l}\text { Environmental } \\
\text { impact }\end{array}$ & Non-destructive & Destructive & Non-destructive \\
\hline $\begin{array}{l}\text { Processing of } \\
\text { samples }\end{array}$ & $\begin{array}{l}\text { No treatment of } \\
\text { samples required }\end{array}$ & $\begin{array}{l}\text { Separation and weight of } \\
\text { macroalgae required }\end{array}$ & $\begin{array}{l}\text { No treatment of } \\
\text { samples required }\end{array}$ \\
\hline Assessment time & $\begin{array}{l}\text { Sedimentation in } \\
10 / 50 / 100 \text { ml Utermöhl } \\
\text { chambers }^{\mathbf{a}}\end{array}$ & $\begin{array}{l}\text { Immediate assessment } \\
\text { in } 1 \mathrm{ml} \text { chambers }\end{array}$ & $\begin{array}{l}\text { Immediate assessment } \\
\text { in } 1 \mathrm{ml} \text { chambers }\end{array}$ \\
\hline $\begin{array}{l}\text { Temporal (daily) } \\
\text { variability }\end{array}$ & $\begin{array}{l}\text { High variability linked to } \\
\text { mechanical cells } \\
\text { resuspension and/or } \\
\text { migration }\end{array}$ & $\begin{array}{l}\text { More consistent } \\
\text { measures }^{c}\end{array}$ & $\begin{array}{l}\text { No temporal variability } \\
\text { expected }^{d}\end{array}$ \\
\hline $\begin{array}{l}\text { Substrate-dependent } \\
\text { variability }\end{array}$ & Comparable results $^{\mathrm{e}}$ & Species-specific results ${ }^{\mathbf{f}}$ & Comparable results $^{\mathrm{e}}$ \\
\hline Risk assessment & $\begin{array}{l}\text { Not representative of the } \\
\text { stock of cells }{ }^{\mathbf{g}}\end{array}$ & $\begin{array}{l}\text { Representative of the } \\
\text { stock of cells }^{\text {h }}\end{array}$ & $\begin{array}{l}\text { Representative of the } \\
\text { stock of cells }^{h}\end{array}$ \\
\hline
\end{tabular}

${ }^{\text {a }}$ results are usually 24 hours delayed, due to the sedimentation time (proportional to the height of the column)

$\mathbf{b}$ the sedimentation is required for a precise estimation of very low cell abundances, but not for risk assessment

c but some variability may be observed, linked to resuspension/migration

d biofilm and surrounding water cells are integrated

e not dependent on substratum

f dependent on substratum

$\mathbf{g}$ and therefore not representative of the potential risk

$\mathbf{h}$ and therefore representative of the potential risk 
Materials and Methods

Benthic Dinoflagellates Integrator (BEDI) device

The purpose of the BEDI device is to integrate dinoflagellate cell abundances, both in the biofilm and in the surrounding water. The results can therefore be expressed as the number of cells per seabed surface area (i.e. cells $\mathrm{mm}^{-1}$ ), independent of the substrate (i.e. macroalgal species). The BEDI device isolates a portion of seabed (to the surface for shallow waters or to a defined height for deeper waters) and allows the mechanical resuspension of the cells in the biofilm which are naturally loosely attached to the substratum. Simple calculations, taking into account the size of the BEDI and the depth of the sampled surface, enable assessment of the integrated abundances of cells in the biofilm and in the surrounding water, corresponding to the surface area sampled.

The BEDI device tested on Mediterranean Ostreospsis cf. ovata blooms consists of a hollow plastic cylinder (Fig. 2a), open at both ends, with a height of $70 \mathrm{~cm}$ and a diameter of $25 \mathrm{~cm}$ (sampled area of $491 \mathrm{~cm}^{2}$ ). A rubber seal is fixed to the bottom of the device, in order to avoid cell loss when sampling irregular seabed (i.e. high complexity rocky bottoms). As Ostreopsis blooms occur in very shallow waters in the Mediterranean Sea, the upper part of the BEDI device can be kept out of the water. In this case, the depth of each sample had to be noted, in order to calculate the total volume of water sampled and correctly estimate the abundance $\mathrm{mm}^{-}$ ${ }^{1}$. Scales can be reported both inside and outside the BEDI device to help with this measure (Fig 2a). For application in deeper environments, the BEDI device has to be sealed at the top to avoid cell loss resulting from mixing of the water and resuspension of cells. A plankton net with an elastic fastening or a hole with a rubber seal can both be used as closing systems for underwater sampling.

During BEDI sampling, the device is placed over the seabed (Fig 2b) and the water inside is vigorously stirred using a standard hand-paddle, allowing the resuspension of cells in the biofilm and their homogenization with the cells in the surrounding water (Fig 2c). The mixing action represents a potential source of variability and the use of a standard oval shaped handpaddle $\left(281 \mathrm{~cm}^{2}\right)$ has been proposed in order to reduce the bias. As Ostreopsis cells (and dinoflagellate cells in general) are loosely attached to the substrate, the variability linked to different observers should be negligible since the water is stirred vigorously inside the BEDI. The water has to be mixed for a few seconds, in order to allow complete resuspension of cells 
and mixing of the water, without facilitating the loss of cells from the bottom. For the Mediterranean Sea Ostreopsis blooms, roughly 5 seconds stirring was applied. Immediately after stirring, a sample is taken from the center of the BEDI column using a $250 \mathrm{ml}$ plastic bottle (Fig 2d). After sampling, the BEDI device can be immediately moved to another site and a new sample taken.

In the case of major blooms, with thick biofilms, a small amount of cells may not be resuspended and may still be found in the biofilm; however, this is difficult to measure. In that case, integrated cells per surface unit may be slightly underestimated relative to the real value.

A

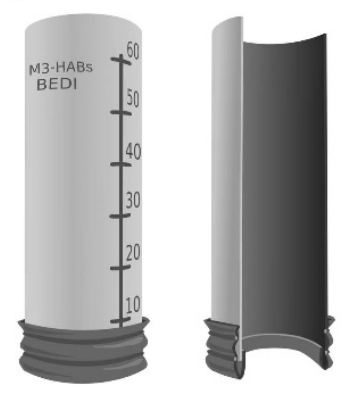

C

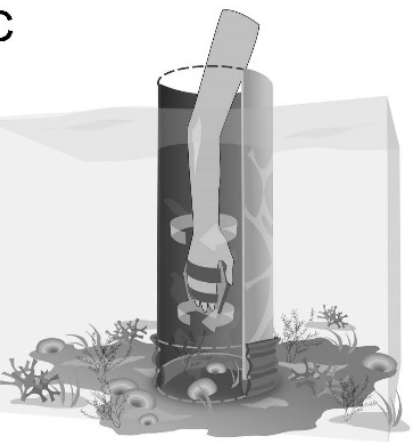

B

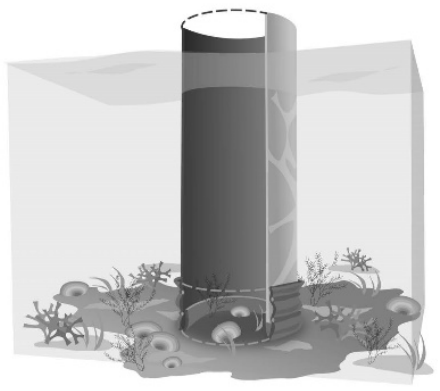

D

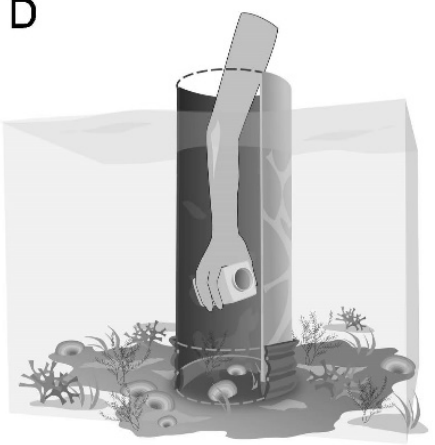

Fig. 2. Scheme of Benthic Dinoflagellates Integrator (BEDI) and its application in shallow waters (nearly $50 \mathrm{~cm}$ depth); a) BEDI device (70 $\mathrm{cm}$ in height; $25 \mathrm{~cm}$ diameter); b) installation over the seabed during sampling procedure; c) resuspension and homogenization of cells of the biofilm in the surrounding water by mixing; d) collection of a water sample using a $250 \mathrm{ml}$ plastic flask.

First BEDI application

The BEDI device was tested during the 2014 Ostreopsis cf. ovata bloom season (mid-summer to early autumn), in the French Ligurian Sea. 


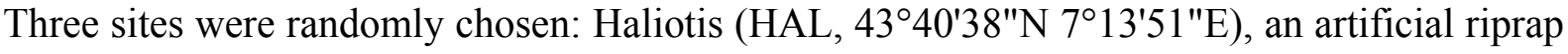
near Nice Côte d'Azur airport, Rochambeau (ROC, 4341'35"N 7¹8'31"E) and Grasseuil (GRA, 4341'59"N 7¹9'20"E), two mixed artificial-natural zones at Villefranche-sur-mer Bay (Fig. 3). At the three sites, the macroalgal assemblages were similar, mostly lacking complex large brown algal forests and therefore being mostly dominated by ephemeral erect or turf forming algae (e.g. Halopteris scoparia, Padina pavonica, Dictyota spp., Corallina elongata, Jania rubens, accompanied by other small red and brown turf-forming algae).

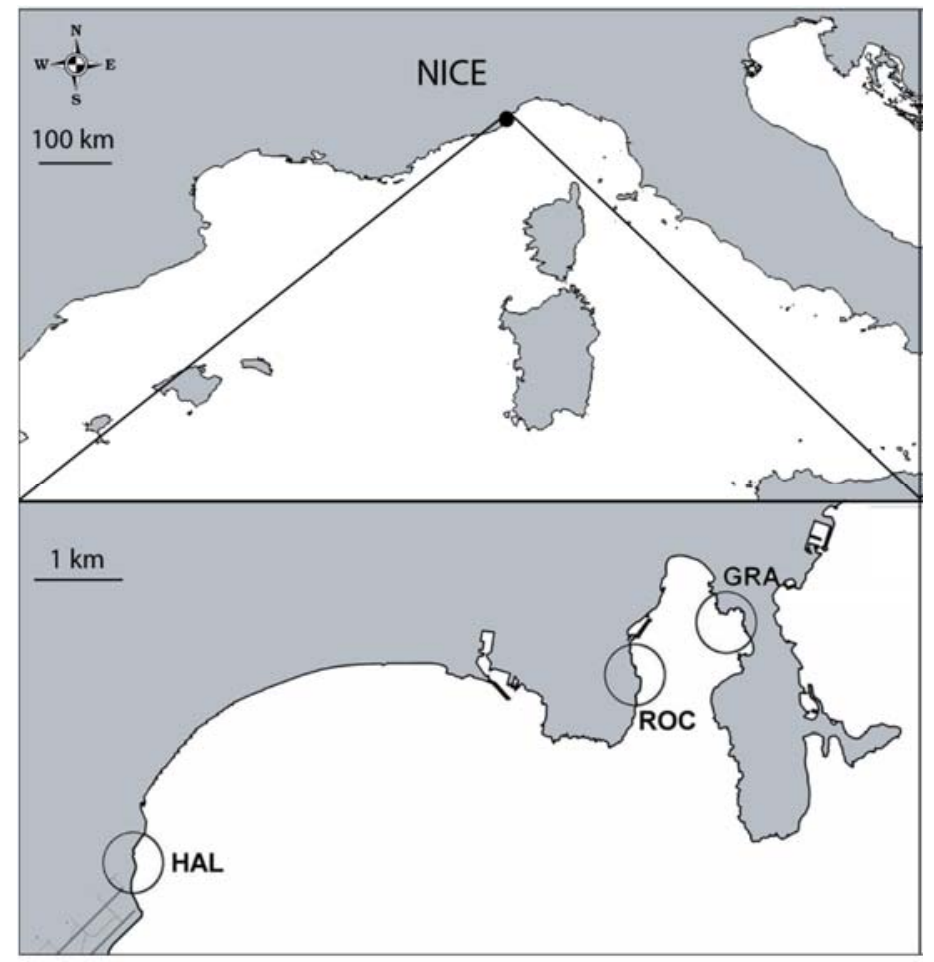

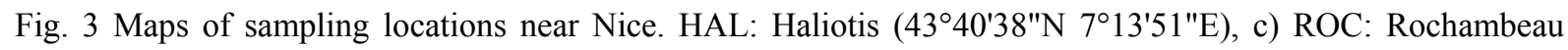

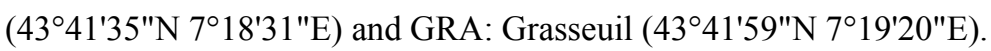

In agreement with the temporal dynamics of Ostreopsis blooms in the Northwestern Mediterranean Sea (Mangialajo et al., 2011), samplings were performed on 7 dates (July 23, 28, 30; August 12, 20, September 9 and October 29, 2014).

At each site (HAL, ROC and GRA), three replicated samplings, 10 meters apart, were performed at the 7 sampling times (T1 to T7); in order to test the replicability of the BEDI measures, 3 replicate bottles were sampled for each measurement.

The three sites were sampled on the same day, except for the first sampling date, where the three sites were visited on two days, the $23^{\text {rd }}$ and $24^{\text {th }}$ of July. For logistical reasons, only two 
sites were sampled on $28^{\text {th }}$ July (ROC and GRA) and $29^{\text {th }}$ October (HAL and ROC). To avoid potential bias due to the daily variation of Ostreopsis abundance (Vila et al., 2001), the order of the sampling sites was interspersed on the different sampling dates.

Comparison with classical methods

To compare the BEDI abundances with other commonly used measurements, parallel biofilm and surrounding water measurements were performed. Cell concentration in the surrounding water was estimated in a water sample taken approx. $20 \mathrm{~cm}$ above the macroalgae, using a 250 $\mathrm{ml}$ plastic bottle. Cell abundances in the biofilm were estimated by collecting 5-10 $\mathrm{g}$ of macroalgae. In order to minimize species-specific variability, the same macroalgal species (Halopteris scoparia) was always collected: this species is very common at the three sites studied and has been proven to support Ostreopsis development in former studies (e.g. Cohu et al. 2011).

To avoid bias due to mechanical resuspension during sampling activities, the surrounding water sample was always collected first, taking care not to resuspend cells, then the biofilm sample and lastly the BEDI sample were collected.

Sample treatment and quantification of cells

In the laboratory, samples were fixed with acidic Lugol, to a final concentration of $1 \%$ solution of Lugol:seawater. A total of 171 BEDI, 63 benthos and 63 plankton samples were collected, fixed and counted.

As no preliminary treatment is needed for BEDI and seawater samples, they were directly stored in the dark. Macroalgal samples were treated as in Cohu et al. (2011).

Cell concentrations in the water samples were assessed following the Utermöhl method (Utermöhl, 1958), counting settled cells in $50 \mathrm{ml}$ sedimentation chambers under an inverted light microscope. Abundances of Ostreopsis in samples collected with the BEDI method were assessed without sedimentation in $1 \mathrm{ml}$ Sedgewick Rafter counting chamber under standard light microscopy. In order to have precise estimations of BEDI samples abundances, when the number of Ostreopsis cf. ovata in the counting chamber was lower than 20 cells (82 samples, 
most of them from GRA), the sample was re-counted using the Utermöhl method $(50 \mathrm{ml}$ sedimentation chamber).

Cell abundances on macroalgae were assessed without sedimentation, in $1 \mathrm{ml}$ Sedgewick Rafter counting chambers under standard light microscope.

\section{Biofilm:surrounding water cells ratio}

The ratio of cells present in the biofilm to cells present in the surrounding water per unit of seabed surface area was calculated according to:

$$
\mathrm{R}_{\mathrm{B} / \mathrm{W}}=\text { CELLSBIOFILM/CELLSWATER. }
$$

To estimate the cell abundances in the biofilm, the total amount of cells in the water column was subtracted from the cells in the BEDI:

\section{CELLS $\mathrm{BIOFILM}=\mathrm{CELLS}$ BEDI - CELLSWATER}

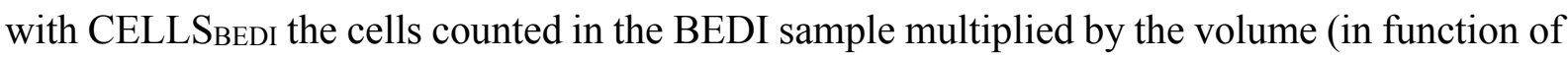
the depth) and CELLSWATER the cells $\mathrm{ml}^{-1}$ estimated in the surrounding water sample, multiplied by the volume of the BEDI sampled (in function of the depth).

The calculation was performed for all samples with $>20$ cells/counting chamber (in order to exclude raw approximation of abundances and zeros at the denominator). A total of 48 samples were used for this calculation, the limiting estimations being mostly the concentrations in the surrounding waters $(20$ cells in the $50 \mathrm{ml}$ Utermöhl sedimentation chamber corresponding to 400 cells $\left.1^{-1}\right)$.

\section{Thresholds predictions}

The threshold concentrations commonly used for monitoring are based on the concentrations of cells in the water (Tichadou et al., 2010, Lemée et al., 2012; Funari et al., 2015). Such values derive from measures performed the day after outbreaks of symptoms in beachgoers (for inhalation of aerosols and dermal exposure), or on the basis of calculations of hypothetical toxicity of ingested seawater (Funari et al., 2015). Such thresholds may potentially change in the future, after more detailed epidemiological studies, but at present they represent the reference monitoring protocols in several Mediterranean countries. Scientists usually prefer to 
assess magnitude of blooms on the basis of cell abundance per gram of fresh weight (FW) of macroalgae. As discussed at recent meetings (i.e. of the European Project M3-HABs), an Ostreopsis cf. ovata 'bloom' in the North Western Mediterranean Sea may be defined as 200,000 cells $\mathrm{g}^{-1}$ of Halopteris (FW) and a 'major bloom' as 1,000,000 cells $\mathrm{g}^{-1}$ of Halopteris (FW).

Based on the regression lines calculated at HAL and ROC (GRA site was excluded because the correlation between BEDI and seawater was not statistically significant), the corresponding BEDI values in both cells $\mathrm{mm}^{-1}$ and PRcells $\mathrm{ml}^{-1}$ are predicted for both monitoring and bloom definition thresholds. On the basis of this comparative study, the thresholds commonly used by agencies for risk assessment (based on water samples) and the values associated by scientists with the definition of 'Ostreopsis cf. ovata bloom' (based on biofilm samples) can be compared.

\section{Statistical analyses}

Variability of Ostreopsis abundances in space (sites) and time (sampling dates) was assessed by multifactorial ANOVAs performed on permutations (PERMANOVA, software PRIMER 6); distance matrices were based on Euclidean distances, corresponding to a classical ANOVA (but releasing the assumptions of normality and homoscedasticity of data). The pseudo-F and corresponding $\mathrm{p}$ values were obtained after 999 permutations and Monte Carlo $\mathrm{p}$ values were considered for post hoc tests when unique values were too low for correct estimation of $p$ values).

The relationships between BEDI, biofilm and surrounding water Otreopsis abundances were analyzed using Pearson linear correlation.

\section{Results}

The linear correlations of the Ostreopsis abundances estimated with the three different sampling techniques (BEDI, biofilm and surrounding water samplings) are reported, for each site, in Fig.4. At GRA, where Ostreopsis abundances remained low for the whole period, only the correlation between BEDI and biofilm abundances was significant, even if weak $\left(\mathrm{R}^{2}=0.2738\right)$. At ROC, the BEDI abundances were also significantly correlated with the concentration of cells in the surrounding water (but at a lower $\mathrm{R}^{2}$ value), while at HAL, where the bloom was greater 
(see below), the combinations of the three methods were significantly correlated (including biofilm and surrounding water).
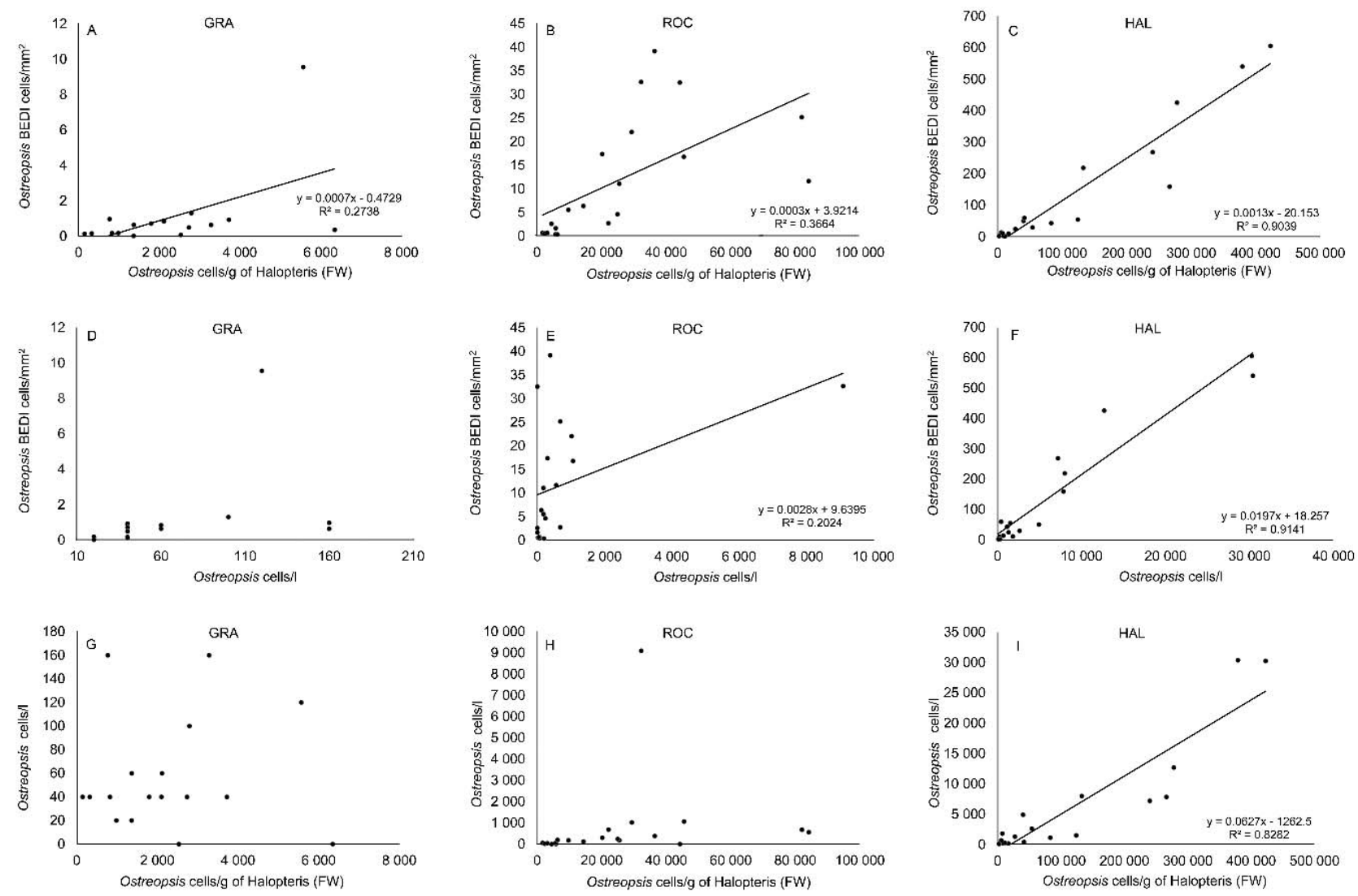

Fig. 4. Ostreopsis cf. ovata scatter plot and regression lines (when Pearson correlation resulted significant) between the abundances calculated with the three methods (BEDI, biofilm, surrounding water) at each site. Correlation between BEDI and biofilm cell abundances at: a) GRA, b) ROC and c) HAL; correlation between BEDI cell abundances and surrounding water cell concentrations at d) GRA, e) ROC and f) HAL; correlation between surrounding water cell concentrations and biofilm cell abundances g) GRA, h) ROC and i) HAL.

The variability at the considered spatial and temporal scales was high, as shown by the significant interaction between the two major factors investigated (Sites x Time, Table 2), independently of the method applied (BEDI, biofilm and surrounding water measures). In general, post hocs demonstrate time-dependent significant differences among the sites, with a bloom at HAL that was consistently higher than at the other two sites. Here the maximum values of BEDI ( 980 cells mm $\left.\mathrm{mm}^{-1}\right)$, biofilm $\left(359.9 \times 10^{3}\right.$ cells $\mathrm{g}^{-1}$ of FW of Halopteris) and surrounding water $\left(30.4 \times 10^{3}\right.$ cells $\left.1^{-1}\right)$ abundances were recorded, all on the same sampling date, the $23^{\text {rd }}$ of July. From a risk assessment point of view, these values corresponded to $2.8 \times 10^{3}$ PRcells $\mathrm{ml}^{-1}$ (Potentially Resuspended cells $\mathrm{ml}^{-1}$ ). The bloom at ROC was higher than at GRA on two 
out of the 7 sampling dates, while at the end of the bloom (September and October samplings), no significant differences between the three sites were recorded.

Table 2. Results of permutational multivariate analysis of variance (PERMANOVA) of abundances of Ostreopsis cf. ovata cells calculated with the three studied methods (BEDI abundances, cells $\mathrm{cm}^{-2}$; biofilm abundances, cells $\mathrm{g}^{-1} \mathrm{FW}$ of macroalga; surrounding water abundances, cells ${ }^{-1)}$. In bold significant values; pairwise tests are reported in Fig. 5.

\begin{tabular}{|l|lccc|ccc|ccc|}
\hline & \multicolumn{4}{|c|}{ BEDI cells cm $^{-2}$} & \multicolumn{3}{|c|}{ Biofilm cells g ${ }^{-1}$ of macroalga } & \multicolumn{3}{|c|}{ Surrounding water cells $1^{-1}$} \\
\cline { 2 - 10 } Source & Df & MS & $\begin{array}{c}\text { Pseudo- } \\
\text { F }\end{array}$ & $\begin{array}{c}\text { P } \\
\text { (perm) }\end{array}$ & MS & $\begin{array}{c}\text { Pseudo- } \\
\text { F }\end{array}$ & P & MS & Pseudo- & $\begin{array}{c}\text { P } \\
\text { (perm) }\end{array}$ \\
\hline Site & 2 & 20133.0 & 3.7823 & $\mathbf{0 . 0 0 6}$ & $7.8724 \mathrm{E} 10$ & 4.4034 & $\mathbf{0 . 0 0 9}$ & $2.0853 \mathrm{E} 8$ & 2.8526 & $\mathbf{0 . 0 0 8}$ \\
Time & 6 & 4584.7 & 0.8761 & 0.652 & $2.1235 \mathrm{E} 10$ & 1.2053 & 0.284 & $9.7572 \mathrm{E} 7$ & 1.3603 & 0.241 \\
Si x Ti & 10 & 5339.8 & 5.2994 & $\mathbf{0 . 0 0 1}$ & $1.7734 \mathrm{E} 10$ & 23.171 & $\mathbf{0 . 0 0 1}$ & $7.3356 \mathrm{E} 7$ & 9.9627 & $\mathbf{0 . 0 0 5}$ \\
Res & 36 & 1007.6 & & & $7.6536 \mathrm{E} 8$ & & & $7.3631 \mathrm{E} 6$ & & \\
Total & 54 & & & & & & & & & \\
\hline
\end{tabular}

Interestingly, the estimations of BEDI and of biofilm abundances gave exactly the same patterns when considering significant differences between paired sites (Fig. 5). Conversely, cells in the surrounding water gave different patterns at 3 sampling times out of seven, but still highlighting the same general trend (Fig. 5).

The analysis of repeatability of BEDI samples showed that no significant variation was observed at this supplementary level of replication (Table 3).

Table 3. Results of permutational multivariate analysis of variance (PERMANOVA) of 3 replicates BEDI dataset $\left(\right.$ cells $\mathrm{mm}^{-2}$ ). In bold, the statistically significant values. No pairwise tests were performed as the term of interest (Station) is a random factor.

\begin{tabular}{c|crrr} 
Source & Df & MS & Pseudo-F & P (perm) \\
\hline Site & 2 & $3.1976 \mathrm{E} 5$ & 2.7739 & $\mathbf{0 . 0 5 7}$ \\
Time & 6 & $1.1152 \mathrm{E} 5$ & 0.9806 & 0.477 \\
Station $(\mathrm{Si})$ & 6 & 1499.5 & 0.6935 & 0.715 \\
SixTi & 10 & $1.1514 \mathrm{E} 5$ & 53.2750 & $\mathbf{0 . 0 0 1}$ \\
St(Si) x Ti & 31 & 2159.4 & 0.7325 & 0.885 \\
Residuals & 110 & 2947.8 & & \\
Total & 165 & & &
\end{tabular}

The use of the BEDI device allowed, for the first time, the estimation of the relative importance of cells in the biofilm and in the surrounding water per unit of sea floor surface. 
The ratio calculated is very high, with an average of cells in the biofilm of $66 \pm 7.6$-fold greater than the cells in the surrounding water per unit of surface area. This value is quite variable, with a minimum of 17 and a maximum of 106, probably due to the fleeting character of concentrations of cells in the water. A certain variability linked to the macroalgal community composition and/or to the BEDI device measures cannot be excluded. No inverse relation (more cells in the surrounding water than in the biofilm) was observed.
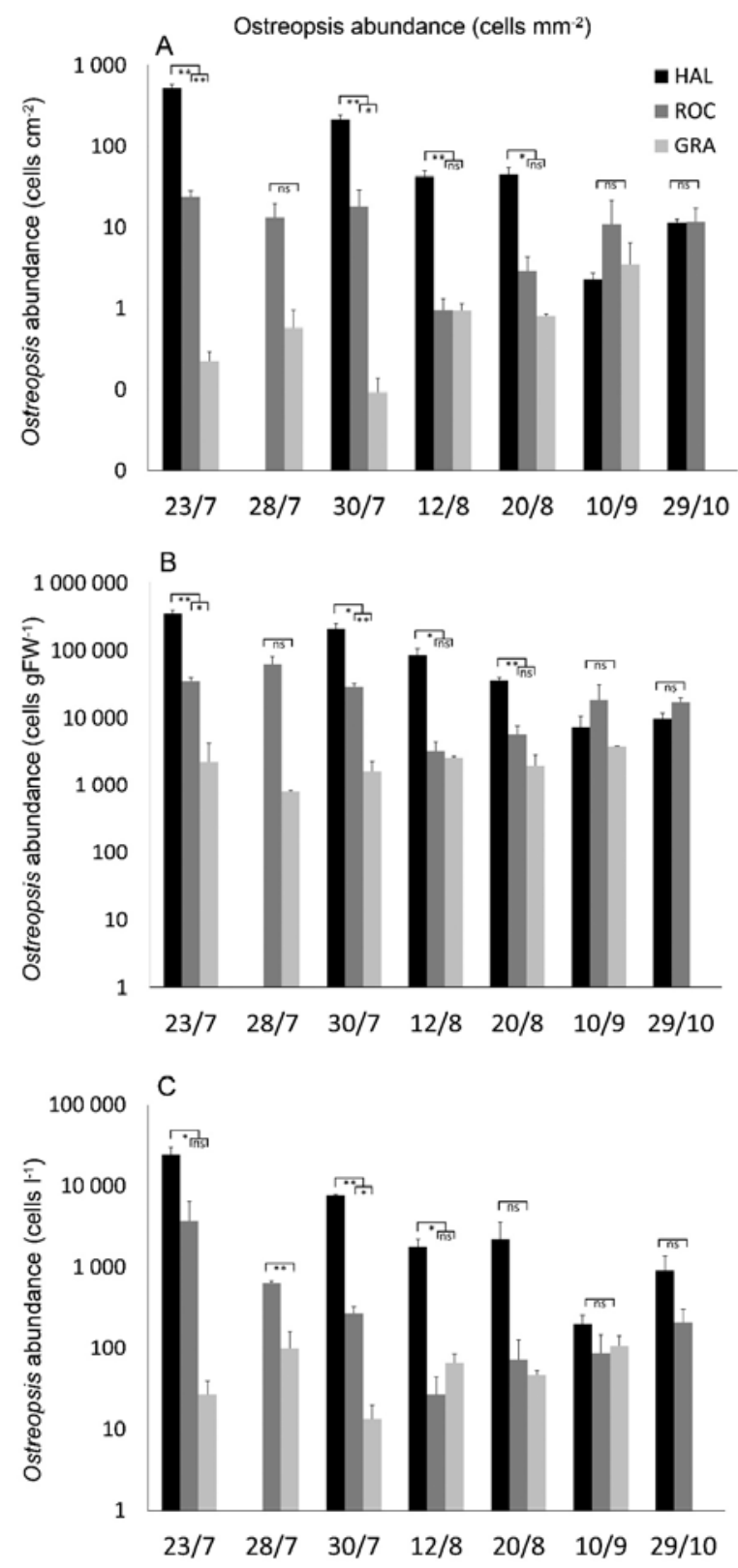

Fig. 5. Ostreopsis cf. ovata abundances at every site X sampling date combination; black bars: HAL; dark grey bars: ROC; light grey bars: GRA; a) BEDI abundances; b) biofilm abundances; c) surrounding water concentrations. Stars indicate different levels of significance of post hoc analyses $(*: p<0.05 ; * *$ : $<<0.01 ; * * *$ : $\mathrm{p}<0.001$ ); ns: not significant ( $>0.05$ ). In red are highlighted the results of surrounding water cell concentrations in disagreement with the patterns highlighted by BEDI and by biofilm abundances. 
The guidelines proposed by Funari et al. (2015) suggest thresholds based on concentrations of cells in the water that provide a basis for planning a three-phase monitoring survey: routine (10 $\times 10^{3}$ cells $\left.1^{-1}\right)$, alert $\left(30 \times 10^{3}\right.$ cells $\left.1^{-1}\right)$, emergency $\left(100 \times 10^{3}\right.$ cells $\left.1^{-1}\right)$. As the same values are also used in other countries (Lemée et al., 2012), predictions for BEDI values (both cells cm ${ }^{-2}$ of seabed and PRCells $\mathrm{ml}^{-1}$ ) were calculated for these three values and are reported in Table 4 . In the same table, the predictions of BEDI values for what can be defined as a bloom $(200 \times$ $10^{3}$ cells $\mathrm{g}^{-1}$ of macroalga $)$ and as a major bloom $\left(1000 \times 10^{3} \mathrm{cells} \mathrm{g}^{-1}\right.$ of macroalga $)$ are reported, as specified in the Materials and Methods section. Interestingly, these values correspond respectively to an intermediate value between routine and alert thresholds and to a value that is quite close to the emergency threshold, as proposed by Funari et al. (2015).

Table 4. Ostreopsis concentration thresholds (cells l $^{-1}$ ) commonly used in monitoring (Tichadou et al., 2010; Lemée et al., 2012; Funari et al., 2015), Ostreopsis cf. ovata abundances used by scientists for definition of blooms (cells g-1 of FW of macroalga) and corresponding predictions of BEDI values (both cells $\mathrm{mm}^{-2}$ and PRcells $\mathrm{ml}^{-1}$ ). Predictions were calculated from the data pooled from ROC and HAL sites, showing significant correlations (GRA site was excluded as the correlations were not always significant).

\begin{tabular}{|c|c|c|c|}
\hline MONITORING & cells $1^{-1}$ of seawater & cells $\mathrm{mm}^{-2}$ & PRcells ml $^{-1}$ \\
\hline Routine & $10 \times 10^{3}$ & 189 & 538 \\
\hline alert & $30 \times 10^{3}$ & 581 & 1656 \\
\hline emergency & $100 \times 10^{3}$ & 1953 & 5568 \\
\hline BLOOM DEFINITION & cells $\mathrm{g}^{-1}$ of macroalga & cells $\mathrm{cm}^{-2}$ & PRcells $\mathrm{ml}^{-1}$ \\
\hline bloom & $200 \times 10^{3}$ & 279 & 816 \\
\hline major bloom & $1000 \times 10^{3}$ & 1319 & 3856 \\
\hline
\end{tabular}

\section{Discussion}

Benthic HABs are socially important at a global scale due to their potential health, ecological and economic impact. Nevertheless, the ecology of benthic dinoflagellates is poorly understood, and this is partly due to the difficulty of assessing their abundance in a reliable and comparable way (Berdalet et al. 2012; Zingone et al., 2012). The BEDI standard assessment method proposed in the present study integrates the dinoflagellate cell abundances in the biofilm and in the surrounding water, allowing the quantification of bloom magnitude over units 
of seabed surface area independently of the substratum (i.e. macroalgal species) or the dominant ecosystem (i.e. algal forests or turfs, seagrass beds, coral reefs).

The BEDI method was successfully applied at three sites in the NW Mediterranean Sea and allowed, for the first time, the calculation of the ratio of Ostreopsis cells in the biofilm and in the surrounding water per surface unit area of seabed. It was previously suggested (Mangialajo et al., 2011 and references therein) that the stock of cells is represented by the biofilm on macroalgae, not in the surrounding water. Here it is shown that this abundance, in shallow environments in the NW Mediterranean Sea, is on average $66 \pm 7.6$ (SE) -fold higher than the cells in the water per a given surface area. This result is particularly significant as it shows that the potential health risk linked to Ostreopsis is in the benthic environment: the biofilm concentrates very high abundances of cells that can be easily re-suspended in the water by mechanical action (waves or trampling) and therefore can be potentially aerosolized, causing symptoms in beachgoers. Current monitoring actions in the Mediterranean Sea are mostly based solely on the assessment of cells in the surrounding water (i.e. Tichadou et al. 2010; Lemée et al., 2012; Funari et al., 2015), which according to the results of the present study, may not be representative of the real public health risk. The mechanical action of stirring when assessing BEDI abundances could be considered a good proxy of mechanical resuspension by waves and/or trampling, and therefore the results, expressed as Potentially Resuspended cells per unit of volume (PRcells $\mathrm{ml}^{-1}$ ), could be used as a direct measure of the potential health risk.

On the basis of the data collected in the present study, regression-based predictions have been calculated for the most recent monitoring thresholds applied in the NW Mediterranean Sea (i.e. Tichadou et al. 2010; Lemée et al., 2012; Funari et al., 2015). On the basis of ten years of Ostreopsis bloom observation in the NW Mediterranean Sea and coordinated research efforts (i.e. the European project M3-HABs), critical values of biofilm cell abundance are proposed for a definition of bloom and major bloom (respectively, $200 \times 10^{3}$ and $1000 \times 10^{3}$ cells g $^{-1}$ of macroalga (FW of Halopteris scoparia)). Corresponding BEDI values have been calculated, and interestingly, a good relation with bloom/major bloom definitions and the thresholds proposed in management guidelines (Funari et al., 2015) is observed. Further epidemiological studies will probably improve the knowledge on these thresholds, and a wider application of BEDI will enable the refinement of the regression line for calculations, providing better tools for the future management of this emergent phenomenon in temperate areas. 
The BEDI standard assessment method is simple, easily applicable and is correlated to the classical estimations (cell abundance in the biofilm and cell concentration in the surrounding water). It is also reliable for repeated sampling, as no significant differences were detected when sampling three replicated measures of each BEDI. These findings are in agreement with the temporal patterns of Ostreopsis blooms observed in the North Western Mediterranean Sea: a peak in July, followed by a decrease in abundances from mid-August (Vila et al., 2001; Mangialajo et al., 2008; Mangialajo et al. 2011; Cohu et al. 2013). BEDI results were consistent with results obtained with the classical methods and the site comparison performed in this study highlighted (independent of the method applied) a high variability in Ostreopsis abundances among sites and sampling times. Inter-site variations of benthic dinoflagellate blooms (at different spatial scales) have been observed in previous studies in tropical (Chang et al., 2000; Parsons and Preskitt, 2007) and temperate (e.g. in New Zealand, Rhodes et al. 2000; in the Mediterranean Sea, Vila et al., 2001; Cohu et al. 2013; in Australia, Skinner et al., 2013) areas. Several factors could explain this variability, including biotic substrate diversity, hydrodynamic conditions and nutrient availability, but more detailed studies would be necessary to disentangle the potential drivers of blooms.

When taking into account significant differences among the three sites investigated in the present study (HAL, ROC, GRA), exactly the same results were found with the BEDI abundances and the biofilm estimations using the macroalgal sample. When comparing BEDI abundances and surrounding water concentrations, 3 out of 7 pairwise comparisons gave slightly different results, but still highlighting the same general trend. Differences were highly significant at the peak of the bloom, however they were less evident with the decrease of cell abundances in late summer: no significant differences among sites were detected in September and October.

Compared to the classical bHABs sampling methods, the BEDI technique seem to incorporate most of the advantages of both biofilm and surrounding water quantifications (i.e. representative of the stock of benthic cells, no treatment needed in the laboratory, comparable results provided) and none of the disadvantages (i.e. non-destructive sampling, no substrate dependence and low variability expected, Table 1). Nevertheless, certain limitations concerning the sampling and the reliability of results should be highlighted:

1) the device is more bulky for use in the field than the bottles needed to sample biofilm/surrounding water samples; 
2) the resuspension of cells should be better standardized than the simple use of a fixed area hand-paddle device (i.e. automatic mixing to be integrated in the device),

3) in the case of major blooms with thick biofilms, some of the cells may not be resuspended and therefore the integrated values may be slightly underestimated. Yet this measure, based on mimicked mechanical action of waves/trampling, still represents the best approximation of the number of cells potentially resuspended in the water that could directly or indirectly (via aerosols) affect beachgoers;

4) in the case of low cell abundances in the biofilm, the concentration of resuspended cells may not be high enough to allow a precise quantification of integrated abundances with the $1 \mathrm{ml}$ Sedgewick-Rafter chambers. In this case, sedimentation in the Utermöhl chamber would be needed to have precise estimations of the cell abundances for research purposes, but this may not constitute a problem for monitoring and risk assessment purposes. As an example, based on

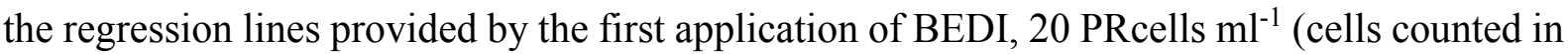
the Sedgewick Rafter chamber, corresponding to the 'Potentially Resuspended cells' per millilitre) correspond to less than 7 cells $\mathrm{mm}^{-2}$ (for an average $35 \mathrm{~cm}$ water depth inside BEDI), to less than 1000 cells g $^{-1}$ for $5 \mathrm{~g}$ of Halopteris scoparia (FW) and to less than 300 cells $^{-1}$ in the surrounding water (per $50 \mathrm{ml}$ sedimentation Utermöhl chamber). All these values are well below the thresholds generally used in monitoring for risk assessment (i.e. Tichadou et al., 2012; Lemée et al., 2012; Funari et al., 2015, Table 4).

Further research may lead to an improvement of the BEDI device presented here, fosteringeven easier and more reliable collection of data. The rationale behind the BEDI is to develop a standardised sampling method providing comparable results, a priority for a better understanding of benthic Harmful Algal Blooms worldwide (Berdalet et al. 2012; Zingone et al., 2012). Only coordinated efforts based on standardized techniques will ensure broad scale knowledge of the bHABs blooms that, when associated with local management actions, could lead to positive developments in the mitigation of blooms and/or a reduction of the potential public health, ecological and economic impact.

\section{Acknowledgements}

The authors wish to thank Alexis Pey for his support in the field and Eric Tanguy and Dominique Delhommeau, of the prototype service of the Observatoire Océanologique de Villefranche for the precious help with the 
realization of first BEDI prototypes. Two anonymous referees gave valuable comments and suggestions that greatly improved the present version of the manuscript. This publication has been produced with the financial assistance of the European Union (EU) under the ENPI CBC Mediterranean Sea Basin Programme (Project M3HABs). The authors wish to thank the co-ordinators of the project (Mariachiara Chiantore and Valentina Asnaghi) for their important work, and also, along with the other partners of the project and participants in the project meetings, for the fruitful and stimulating discussions that greatly improved this paper, in particular with regard to risk assessment and the use of BEDI for monitoring purposes.

\section{BIBLIOGRAPHY}

Abbate, M., Bordone, A., Cerrati G., Di Festa, T., Melchiorre, N., Pastorelli, A.M., Peirano, A., Petruzzelli, M.R., Ungaro, N. 2012. A new method for sampling potentially toxic benthic dinoflagellates. Cryptogamie Algol., 33(2), pp. 165-170.

Accoroni S., Glibert,P.M., Pichierri, S., Romagnoli, T., Marini, M., Totti, C. 2015. A conceptual model of annual Ostreopsis cf. ovata blooms in the northern Adriatic Sea based on the synergic effects of hydrodynamics, temperature, and the N:P ratio of water column nutrients. Harmful Algae 45, pp. 14-25.

Accoroni S., Totti C. 2016. The toxic benthic dinoflagellates of the genus Ostreopsis in temperate areas: a review. Adv. Ocean. Limn. 7, pp. 1-15.

Aligizaki, K., Katikou, P., Nikolaidis, G., Panou, A. 2008. First episode ofshellfish contamination by palytoxinlike compounds from Ostreopsis species (Aegean Sea, Greece). Toxicon 51, 418-427.

Barroso Garcia, P., Rueda de la Puerta, P., Carrano, T.P., Martinez, P.M., Enriquez, E.G., 2008. Brote con sintomas respiratorios en la provincia de Almeria por una posible exposicion a microalgas toxicas. Gac. Sanit. 22, pp. 578584.

Berdalet, E., Bravo, I., Evans, J., Fraga, S., Kibler, S., Kudela, R. M., Larsen, J., Litaker, W., Penna, A., Tester, P., Vila, M., Zingone, A. 2012. GEOHAB. Global Ecology and Oceanography of Harmful Algals Blooms. GEOHAB Core Research Project: HABs Benthic Systems. IOC of UNESCO and SCOR, Paris and Newark, 64 pp.

Biré, R., Trotereau, S., Lemée, R., Delpont, C., Chabot, B., Aumond, Y., Krys S. 2013. Occurrence of palytoxins in marine organisms from different trophic levels of the French Mediterranean coast harvested in 2009. Harmful Algae 28, pp. 10-22.

Biré R., Trotereau S., Lemée R., Oregioni D., Delpont C., Krys S., Guérin T. 2015. Hunt for Palytoxins in a Wide Variety of Marine Organisms Harvested in 2010 on the French Mediterranean Coast. Marine Drugs, 13, pp. 54255446.

Bomber, J.W. 1985. Ecological studies of benthic dinoflagellates associated with ciguatera from the Florida Keys. M.S. Thesis Florida Institute of Technology, Melbourne, FL.

Brissard C., Herrenknecht C., Séchet V., Hervé F., Pisapia F., Harcouet J., Lémée R., Chomérat N., Hess P., Amzil, Z. 2014. Complex toxin profile of French Mediterranean Ostreopsis cf. ovata strains, seafood accumulation and ovatoxins prepurification. Mar. Drugs, 12, pp. 2851-2876. 
Chang, F.H., Shimizu, Y., Hay, B., Stewart, R., Mackay, G., Tasker, R. 2000. Three recently recorded Ostreopsis spp. (Dinophyceae) in New Zealand: temporal and regional distribution in the upper North Island from 1995 to 1997. New Zeal. J. Mar. Fresh. 34, pp. 627-632.

Ciminiello, P., Dell'Aversano, C., Iacovo, E.D., Fattorusso, E., Forino, M., Tartaglione, L., Benedettini, G., Onorari, M., Serena, F., Battocchi, C., Casabianca, S., Penna, A., 2014. First Finding of Ostreopsis cf. ovata Toxins in Marine Aerosols. Environ. Sci. Technol. 48, pp. 3532-3540.

Cohu, S., Mangialajo, L., Thibaut, T., Blanfune' , A., Marro, S., Lemée, R. 2013. Proliferation of the toxic dinoflagellate Ostreopsis cf. ovata in relation to depth, biotic substrate and environmental factors in the North West Mediterranean Sea. Harmful Algae 24, pp. 32-44.

Durando, P., Ansaldi, F., Oreste, P., Moscatelli, P., Gasparini, L.M., Icardi, G. 2007. Ostreopsis ovata and human health: epidemiological and clinical features of respiratory syndrome outbreaks from a two-year sindromi surveillance, 2005-06, in north-west Italy. Eur. Surveill. 12.

Funari, E., Manganelli, M, Emanuela, T. 2015. Ostreospis cf. ovata blooms in coastal water: Italian guidelines to assess and manage the risk associated to bathing waters and recreational activities. Harmful Algae 50, pp. 45-56. Gallitelli, M., Ungano, N., Addante, L.M., Gentiloni, N., Sabba, C. 2005. Respiratory illness as a reaction to tropical algal blooms occurring in a temperate climate. JAMA 293, pp. 2599-2600.

Granéli, E., Vidyarathna, N. K., Funari, E., Cumaranatunga, P.R.T., Scenati, R. 2011. Can increases in temperature stimulate blooms of the toxic benthic dinoflagellate Ostreopsis ovata? Harmful Algae 10, pp. 165-172.

Jauzein, C., Fricke, A., Mangialajo, L., Lemée, R., 2016. Sampling of Ostreopsis cf. ovata using artificial substrates: optimization of methods for the monitoring of benthic harmful algal blooms. Mar. Pollut. Bull., 107: 300-304

Lemée, R., Mangialajo, L., Cohu S., Amzil Z., Blanfuné, A., Chomerat, N., Ganzin, N., Gasparini, S., Grossel, H., Guidi-Guilvard, L., Hoareau, L., Le Duff, F., Marro, S., Simon N., Nezan, E., Pedrotti, M.L., Sechet, V., Soliveres, O., Thibaut, T. 2012. Interactions between scientists, managers and policy makers in the framework of the French MediOs project on Ostreopsis. 2008-2010. Cryptogamie, Algol., 33 (2), pp. 137-142.

Litaker, R. W., Vandersea, M. W., Faust, M. A., Kibler, S. R., Nau, A. W., Holland, W. C., Chinain, M., Holmes, M. J., Tester, P. A. 2010. Global distribution of ciguatera causing dinoflagellates in the genus Gambierdiscus. Toxicon 56, pp. 711-730.

Llewellyn, L.E. 2010. Revisiting the association between sea surface temperature and the epidemiology of fish poisoning in the South Pacific: Reassessing the link between ciguatera and climate change. Toxicon 56, pp. 691697.

Lobel, P.S., Anderson, D.M., Durand-Clement, M. 1988. Assessment of ciguatera dinoflagellate populations sample variability and algal substrate selection. Biol. Bull. 175, pp. 94-101.

Mangialajo, L., Bertolotto, R., Cattaneo-Vietti, R., Chiantore, M., Grillo, C., Lemée, R., Melchiorre, N., Moretto, P., Povero, P., Ruggieri, N. 2008. The toxic benthic dinoflagellate Ostreopsis ovata: Quantification of proliferation along the coastline of Genoa, Italy. Mar. Pollut. Bull. 56, pp. 1209-1214.

Mangialajo, L., Ganzin, N., Accoroni, S., Asnaghi, V., Blanfuné, A., Cabrini, M., Cattaneo-Vietti, R., Chavanon, F., Chiantore, M., Cohu, S. 2011. Trends in Ostreopsis proliferation along the Northern Mediterranean coasts. Toxicon 57, pp. 408-420. 
Nakajima, I., Oshima, Y., Yasumoto, T. 1981. Toxicity of benthic dinoflagellates in Okinawa. Bull. Jpn. Soc. Sci. Fish. 47: 1029-1033

Parsons, M.L., Preskitt, L.B. 2007. A survey of epiphytic dinoflagellates from the coastal waters of the island of Hawai' 'i. Harmful Algae 6, pp. 658-669.

Parsons, M.L., Settlemier, C.J., Bienfang, P.K. 2010. A simple model capable of simulating the population dynamics of Gambierdiscus, the benthic dinoflagellate responsible for ciguatera fish poisoning. Harmful Algae 10, pp. 71-80.

Parsons, M. L., Aligizaki, K., Dechraoui Bottein, M-Y., Fraga, S., Morton, S. L., Penna, A., Rhodes, L. 2011. Gambierdiscus and Ostreopsis: Reassessment of the state of knowledge of their taxonomy, geography, ecophysiology, and toxicology. Harmful Algae 14, pp. 107-129.

Rains, K.L., Parsons M.L., 2015. Gambierdiscus species exhibit different epiphytic behaviors toward a variety of macroalgal hosts. Harmful Algae 49: 29-39.

Rhodes, L. 2011. World-wide occurrence of the toxic dinoflagellate genus Ostreopsis Schmidt. Toxicon 57 (3), pp. 400-407.

Rhodes, L., Adamson, J., Suzuki, T., Briggs, L., Garthwaite, I. 2000. Toxic marine epiphytic dinoflagellates, Ostreopsis siamensis and Coolia monotis (Dynophyceae), in New Zealand. New Zeal. J. Mar. Fresh. 34, pp. 371383.

Richlen, L.M., Lobel, S.P. 2011. Effects of depth, habitat, and water motion on the abundance and distribution of ciguatera dinoflagellates at Johnston Atoll, Pacific Ocean. Mar. Ecol. Prog. Ser. 421: 51-66.

Sansoni, G., Borghini, B., Camici, G., Cassoti, M., Righini, P., Rustighi, C. 2003. Fioriture algali di Ostreopsis ovata (Gonyaulacales: Dinophyceae): un problema emergente. Biologia Ambientale 17, pp. 17-23.

Shears, N.T. and Ross, P.M. 2009. Blooms of benthic dinoflagellates of the genus Ostreopsis: an increasing and ecologically important phenomenon on temperate reefs in New Zealand and worldwide. Harmful Algae 8, pp. 916-925.

Shears, N.T. and Ross, P.M. 2010. Toxic cascades: multiple anthropogenic stressors have complex and unanticipated interactive effects on temperate reefs. 2010. Ecol. Lett. 13, pp. 1149-1159.

Skinner, M., T. Brewer, R. Johnstone, L. Fleming y R. Lewis. 2011. Ciguatera fish poisoning in the Pacific Islands (1998 to 2008). PLos Negl. Trop. Dis., 5(12), pp. 1-7.

Skinner, M. P., Lewis, R. J., Morton, S. 2013. Ecology of the ciguatera causing dinoflagellates from the Northern Great Barrier Reef: Changes in community distribution and coastal eutrophication. Mar. Pollut. Bull. 77, pp. 210219.

Tester, P.A., Kibler, S.R., Holland, W.C., Usup, G., Vandersea, M.W., Leaw, C.P., Teen, L.P., Larsen, J., Mohammad-Noor, N., Faust, M.A., Litaker, R.W. 2014. Sampling harmful benthic dinoflagellates: Comparison of artificial and natural substrate methods. Harmful Algae 39, pp. 8-25.

Tichadou L., Glaizal M., Armengaud A., Grossel H., Lemee R., Kantin R., Lasalle J.L., Drouet G., Rambaud L., Malfait P., de Haro L. 2010. Health impact of uni-cellular algae of the Ostreopsis genus blooms in the Mediterranean Sea: ex-perience of the French Mediterranean coast surveillance network from 2006 to 2009. Clin.

Toxicol. 48, pp. 839-844. 
Totti, C., Accoroni, S., Cerino, F., Cucchiari, E., Romagnoli, T. 2010. Ostreopsis ovata bloom along the Conero Riviera (northern Adriatic Sea): Relationships with environmental conditions and substrata. Harmful Algae 9: 233239.

Tubaro, A., Durando, P. Del Favero, G., Ansaldi, F., Icardi, G., Deeds, J.R., Sosa, S. 2011. Case definitions for human poisonings postulated to palytoxins exposure. Toxicon 57 (3), pp. 478-495.

Utermöhl, H. 1958. Zur Vervollkommung der quantitative Phytoplankton - Methodik, Mitteilungen Internationale Vereinigung Theoretische und Angewandte Limnologie 9, pp.1-38.

Vila, M., Camp, J., Garcés, E., Masó, M., Delgado, M. 2001. High resolution spatio-temporal detection of potentially harmful dinoflagellates in confined waters of the NW Mediterranean. J. Plankt. Res. 23, pp. 497-514. Vila M., Abós-Herràndiz R., Isern-Fontanet J., Àlvarez J., Berdalet E. 2016. Establishing the link between Ostreopsis cf. ovata blooms and human health impacts using ecology and epidemiology. Sci Mar 80, 107-115.

Yasumoto, T., Seino, N., Murakami, Y., Murata, M., 1987. Toxins produced by benthic dinoflagellates. Biol. Bull. 172: $128-131$.

Zingone, A., Berdalet, E., Bienfang, P., Enevoldsen, H., Evans, J., Kudel, R., Tester, P. 2012. Harmful algae in benthic systems: A GEOHAB core research program. Cryptogamie, Algol. 33: 225-230. 